\title{
The elusive quest for the rule of law: promoting judicial reform in Latin America
}

\author{
A indescritivel busca pelo estado de direito: \\ promovendo a reforma judicial na América Latina
}

CARLOS SANTISO*

RESUMO: Embora exista um consenso sobre a centralidade do estado de direito tanto para o desenvolvimento econômico quanto para a consolidação democrática, a economia política da reforma legal e judicial permanece em grande parte sub-teorizada. O ensaio de revisão ressalta as tensões e trade-offs entre as diferentes estratégias e objetivos da reforma judicial na América Latina. Contrastando as experiências da Argentina e do Brasil, destaca o delicado equilíbrio entre independência e responsabilidade. Também avalia o papel das instituições doadoras, e em particular dos bancos multilaterais de desenvolvimento, na promoção da reforma judicial. Defende uma abordagem mais realista da governança judicial, concentrando-se em reformas viáveis.

PALAVRAS-CHAVE: Estado de direito; reforma da justiça; instituições de accountability; América latina; Brasil; Banco Mundial; Banco Interamericano de Desenvolvimento.

ABSTRACT: While there exists a consensus on the centrality of the rule of law both for economic development and democratic consolidation, the political economy of legal and judicial reform remains largely under-theorized. The review essay underscores the tensions and trade-offs between the different strategies and objectives of judicial reform in Latin America. Contrasting the experiences of Argentina and Brazil, it high- lights the delicate balance between independence and accountability. It also assesses the role of donor institutions, and in particular the multilateral development banks, in promoting judicial reform. It argues for a more realistic approach to judicial governance, focusing on feasible reforms.

KEYWORDS: Rule of law, justice reform; accountability institutions; Latin America; Brazil; World Bank; Inter-American Development Bank.

JEL Classification: F35; K00; H81; H83.

\footnotetext{
* Departamento de Economia, Universidade de São Paulo, São Paulo/SP, Brasil. E-mail: frocha@usp.br. Submetido: 5/Janeiro/2002;Aprovado: 4/Abril/2002.
} 


\section{BOOKS REVIEWED}

- Governing for Prosperity. Bruce Bueno de Mesquita and Hilton Root, eds.

- (New Haven: Yale University Press, 2000);

- Elusive Reform: Democracy and the Rule of Law in Latin America. Mark

- Ungar (Boulder: Lynne Rienner Publishers, 2002);

- Rule of Law in Latin America: The International Promotion of Judicial Reform. Pilar Domingo and Rachel Sieder. eds. (London: University of London, 2001);

- Guidance for Promoting Judicial Independence and Impartiality. United States Agency for International Development (Washington DC: USAID Office of Democracy and Governance);

- Reforming Public Institutions and Strengthening Governance: A World Bank

- Strategy. The World Bank (Washington DC: World Bank Public Sector Group);

- Reforma do Judiciário. Maria Tereza Sadek, ed. (São Paulo, Brazil: Fundação Konrad Adenauer);

- The Judiciary and Democratic Decay in Latin America: Declining Confidence in the Rule of Law. William C. Prillaman (Westport: Praeger, 2000);

- Justice Delayed: Judicial Reform in Latin America. Edmundo Jarquín and Fernando Carrillo, eds. (Washington DC: Inter-American Development Bank, 1998).

\section{INTRODUCTION}

Strengthening the rule of law and adequately reforming judicial institutions have become core objectives of policymakers in developing countries and transition economies. They have also become, in the course of the 1990s, a major concern of international financial institutions and donor governments in their efforts to promote democracy abroad. Yet, the political economy of judicial reform remains largely under-studied and significantly under-theorized (Messick, 1999; Dodson, 2002). Moreover, the assistance provided by multilateral institutions and donor agencies has also received scant attention. In recent years, however, the promotion of judicial reform is receiving greater scrutiny, as donor organizations seek to evaluate the impact of their interventions.

A broad consensus has emerged on the centrality of the rule of law in the second stage of reform (Santiso, 2001a). The prevailing development paradigm rooted in the neo-liberal precepts of the Washington Consensus has elevated the rule of law to the altar of the institutional reforms required to sustain market reforms. As Edgardo Buscaglia (2002:137) aptly remarks, "the mix of increasing political de- 
mocratization and the adoption of market reforms has created additional, but unfulfilled, demands for improvements in legal and judicial frameworks throughout the developing world, fostering the need for more effective private and public dispute resolution". Furthermore, the instability in international financial markets has shaken once promising emerging market economies and uncovered the "fault lines" of democratic governance (Agüero and Stark, 1998).

However, beyond generous statements of intentions and sweeping assertions on the centrality of the rule of law for both economic development and democratic consolidation, the political economy of legal and judicial reform remains a mystery. Little is known on how to adequately reform judicial systems and more fundamentally how to strengthen the rule of law. Furthermore, the rule of law remains an elusive concept, trapped in the increasing confusion of the post-Washington consensus. The plasticity of the concept hinders the identification of indicators of judicial performance and the definition of effective strategies for judicial reform. There are still no clear or settled ideas about how the rule of law should be suitably defined, let alone how rule of law reform can be appropriately incorporated into externally-financed programs of institutional development.

The books reviewed in this essay constitute important and timely contributions to the political economy of judicial reform, the findings of which apply beyond Latin America. This review essay also scrutinizes the strategies of the international financial institutions and donor governments aimed at strengthening the rule of law abroad, questioning their theoretical underpinnings and conceptual foundations. By doing so, it attempts to bridge research and policy by including both academic studies and practitioners' analyses. As such, it aims at crossing the traditional boundaries of academic disciplines and breaching the chasm between research and policy, which, unfortunately, still rarely meet.

\section{THE POLITICAL ECONOMY OF JUDICIAL REFORM}

\section{The Rule of Law and Democratic Governance}

Since the late 1980s, Latin America has experienced a momentum for reforming judicial systems. Enhancing the rule of law has become the new miraculous cure to palliate the unfulfilled expectations of democracy and the market economy (Carothers, 1998). While democracy as a political regime has spread across Latin America, its durability is threatened by the gradual erosion of governance, democratic decay and the declining confidence in the rule of law. What Juan Mendez et al. (1999) have described as the 'un-rule of law' of rising crime and incivility reflects the inherent weakness of the state and the institutional mechanisms of "horizontal accountability" (O'Donnell 1998 and Schedler et al 1999). Endemic corruption further undermines the public trust in democratic institutions, revealing their intrinsic flaws.

Consolidating democracy and anchoring market reform remains a central 
challenge for Latin America, a task further complicated by the backlash against the neoliberal model gaining momentum in the aftermath of the implosion of the Argentine economy. As the books reviewed hereafter underscore, legal and judicial reform must be placed within the broader context of the modernization of the state and the reform of the modes of governance required to consolidate democracy (Santiso, 2001a and b). Adherence to the rule of law is believed to be an essential determinant of the quality of governance and a fundamental requisite for successful economic reform. For example, for a sample of 28 countries, Beatrice Weder (1994) finds that the degree of credibility and stability in the rules and procedures of the various legal systems explains 23 percent of the variation in per capita growth. The lack of credibility of and confidence in the judiciary constitutes a central dimension of the current institutional crisis of governance threatening the stability of democracy in many countries of the region, from Nicaragua to Argentina.

Governing for Prosperity confronts the central paradox of the political economy of policy reform and institutional development: "if the knowledge of what makes markets work is widely known, then we must explain why so many governments resist changing their policies and their institutions until forced to do so in order to surmount a crisis" (7). Editors Bruce Bueno de Mesquita and Hilton Root go beyond the traditional debates on the relationship between regime type and economic performance, to address shortcomings in the conduct of public policy. Their aim is to investigate the structural incentives shaping public policymaking to elucidate "when bad economics is good politics" (1). They convincingly argue that democracy in itself is not sufficient to promote good policies, as "democratic governance does not necessarily engender effective policy performance" (9). However, as they are more responsive to the median voter, democratic governments are more likely to focus their efforts on resolving co-ordination problems and seek to enhance the transparency of laws and regulations, while autocratic regimes emphasize opaqueness and opacity that contribute to discretion. As Root and Nellis argue, "governments that create information asymmetries cannot be expected to intervene to make markets more efficient" (85).

Comprehensive state reform is nevertheless hampered by its weakness and, in many instances, its capture by complex patronage networks. Indeed, the forced shrinkage of the state in the wake of neo-liberal reforms has undermined the state's capacity for policymaking and law enforcement. In extreme cases of state failure, lawmaking and policy formulation are themselves captured by narrow interest groups so that rules and regulations are adopted or modified to fit their preferences. State capture, which occurs when political power itself is used for private gains as a result of inappropriate patterns of public spending and resource allocation, is more damaging than state corruption and particularly difficult to confront. Bribery is only the tip of the iceberg. Evidence from transition countries in East and Central Europe reveals the devastating effects on governance of systemic corruption and state capture (Hellman et al., 2000). 


\section{The Rule of Law and Economic Development}

In his contribution on democracy and the rule of law, Robert Barro aptly underlines that "the question of which aspects of institutions matter for long-run economic performance has proved to be more controversial than the proposition that institutions are important overall” (209). While the strand of the research that has focused on democracy is largely inconclusive, a more recent strand, which has emphasized judicial security, property rights and legal structures that promote the rule of law, has yielded greater insights.

The economic effects of secure property rights and well-functioning legal systems are reasonably well understood, although recent research suggests that they are not as straightforward as initially assumed. In an insightful study, John Hewko (2002) shows that, in the case of East and Central Europe, an extensive overhaul of a country's legislative and institutional framework is generally not a necessary precondition to attract foreign investment. Significantly more important is the existence of real business opportunities and the possibility to influence specific reforms in the existing legislation. As long as their concerns are addressed and their property rights guaranteed, entrepreneurs are far less sensitive to institutional change than the literature suggests.

The effects of democracy are more complex, in part due to the difficulty in accurately defining governance and adequately measuring institutional quality. Assessing the rule of law also entails problems of its own, as there are no agreedupon international benchmarks against which to gauge performance. Most assessments originate from political risk rating agencies, reflecting the concerns of private investors. They include institutional matters such as the prevalence of the rule of law, the capacity of the legal system to enforce contracts, the efficiency of the bureaucracy, the likelihood of government expropriation and the extent of official corruption.

Barro finds that the index of overall maintenance of the rule of law provides the greatest explanatory power for investment and economic growth. He posits that a higher level of rule of law generates a higher rate of economic growth. The disturbing, yet persuasive conclusion that Barro reaches is that "for a country that starts with weak institutions - low levels of democracy and rule of law - an increase in democracy is less important than an expansion of the rule of law as a stimulus for economic growth and investment". Consequently, "even if democracy is the principal objective in the long run, the best way to accomplish it may be to encourage the rule of law in the short run" (230). However, Barro's sophisticated econometric regression techniques are based on questionable quantitative indicators of the rule of law. The data on the rule of law relies on survey data, reflecting the subjective judgements of individual experts, and is thus marked by a host of accuracy and measurement problems. Although significant progress has been made in recent years to refine them, existing time-series data of institutional quality and governance performance remain unsatisfactory to evaluate dynamic changes over time (Linder and Santiso, 2002). 


\section{The Question of Strategy}

Beyond the, sometimes, esoteric debates on the contribution of the rule of law to economic development, scant attention has been paid to the strategies deployed by reformers to overhaul judicial systems. The problems in assessing judicial reform are further compounded by the lack of consensual and operational definitions of critical concepts such as judicial independence or accountability, as well as the very notion of the rule of law itself. The Judiciary and Democratic Decay in Latin America fills an important gap in the emerging literature on the comparative analysis of the politics of judicial reform. It offers a rigorous framework for evaluating the strategies of judicial reform and suggests measurable indicators of reform performance.

Contrasting the recent experiences of El Salvador, Brazil, Argentina and Chile, William Prillaman assesses the goals and means of judicial reform along two main axes of enquiry, one tackling the objectives (or targeting) of judicial reform and a second one assessing the strategies (or sequencing). Prillaman's case studies illustrate the contribution of constitutional engineering and institutional design to strengthen or weaken the rule of law. The four main objectives of judicial reform include (i) enhancing the independence and impartiality of the judiciary, (ii) improving the efficiency of the courts, (iii) facilitating access to justice; and (iv) strengthening judicial accountability. The two main reform trajectories are (i) an incremental and sequential approach and (ii) a radical and simultaneous approach. According to this analytical framework, the reform trajectories of the four country cases are captured in the following table.

Table: Approaches to J udicial Reform

\begin{tabular}{|c|c|c|c|c|c|c|}
\hline & \multicolumn{3}{|c|}{ Objectives } & \multirow[b]{2}{*}{ Access } & \multicolumn{2}{|c|}{ Strategy } \\
\hline & Independence & Accountability & Efficiency & & Simultaneous & Sequential \\
\hline $\begin{array}{l}\text { Argentina } \\
\text { 1983-1989 }\end{array}$ & $\checkmark$ & & & & & $\checkmark$ \\
\hline 1989-1999 & & & $\checkmark$ & $\checkmark$ & & \\
\hline $\begin{array}{l}\text { Brazil } \\
\text { 1988-2000 }\end{array}$ & $\checkmark$ & & & $\checkmark$ & & $\checkmark$ \\
\hline $\begin{array}{l}\text { Chile } \\
\text { 1990-2000 }\end{array}$ & $\checkmark$ & $\checkmark$ & $\checkmark$ & $\checkmark$ & $\checkmark$ & \\
\hline $\begin{array}{l}\text { El S alvador } \\
1984-2000\end{array}$ & $\checkmark$ & & $\checkmark$ & & & $\checkmark$ \\
\hline
\end{tabular}

Questioning the original assumptions of reformers, Prillaman demonstrates, quite persuasively, that all components of judicial reform are not necessarily mutually reinforcing, as they may generate unintended "negative synergies": While "there may be no clear maps for success, there are many roads to failure" (75). $\mathrm{He}$ 
argues that a strategy of simultaneous reform on all fronts, such as the one adopted by Chilean reformers, is generally more effective at avoiding undesired consequences than the alternative strategy of staggered gradualism, followed by Honduras.

More fundamentally, Prillaman questions the standard approach to legal and judicial reform. Lacking a general theory of judicial reform, reformers have tended to resort to a technical approach, often mechanically transposing the legal systems of more developed countries. They "typically have focused on a narrow range of variables, seeking first to isolate and consolidate specific individual advances and then move on to other variables in an orderly, sequential fashion [...] One reform is thought to lead naturally to another in an orderly, unilinear fashion" (4-5). Implicit to the standard approach is the assumption that the judiciary itself should lead the reform process. However, a striking point of the case studies under review is the degree to which the judicial hierarchy has consistently opposed reform. This technocratic approach has clearly shown its limits. Prillaman convincingly argues that the original strategy of isolating a single dimension of judicial reform and improving it independently of the other structural flaws is misleading, as "one positive reform does not inevitably lead to another" (6).

Furthermore, finding the right balance between the four main dimensions of judicial impartiality and credibility (independence, accountability, efficiency and access) is a permanent challenge. Most studies of judicial reform tend to presume the existence of a positive synergy or virtuous circle between the different dimensions of judicial reform. Few reformers have foreseen the existence of potential tensions and trade-offs amongst them. Indeed, the most damaging aspect of the failure of judicial reform in Latin America has been the inability to achieve a workable balance between the different dimensions of judicial credibility (Diakolias, 1995; Domingo, 1999). Judicial reform cannot be isolated from broader political and economic dynamics: "Judicial reform, for better or worse, is an inherently political rather than technical process entailing a series of political judgements at every stage" (6). Moreover, the different dimensions of judicial credibility must be evaluated in relative, rather than absolute terms against exogenous standards. Judicial reform is circumstantial and needs to take into account initial conditions. Moreover, variables such as judicial independence, accountability or efficiency are necessarily continuous rather than dichotomous variables.

\section{Balancing Independence and Accountability}

A central concern of most books reviewed herein is the delicate balance between judicial independence and accountability: How much is enough? How much is too much? The main thorny question is not whether or not the judiciary is independent, but rather how independent it should be considering a country's specific circumstances. While the prevailing consensus holds that an independent judiciary is critical for its credibility, reformers have often overlooked the corresponding need to enhance 
accountability. This shortcoming is due, in part, to the fact that accountability is a difficult concept in the democratic framework of the separation of powers.

The contrast between Argentina and Brazil is particularly illustrative in this regard. The case of Brazil illustrates the perils of insularity and unaccountability resulting from excessive independence. In Brazil, "reformers achieved unprecedented levels of structural and individual independence, but, in the process of reacting to more than two decades of military rule, swept aside the balancing constraints of accountability and transparency. By virtually any measure, the courts are irresponsible, inefficient and inaccessible" (94). For example, the judiciary sets and administers its own budget, often with little self-restraint and accountability. Reports of overspending and mismanagement are common. Furthermore, judicial insularity has hampered the implementation of economic reforms, as the Supreme Court has regularly struck down executive decrees or enforced some of the most ill considered portions of the Constitution. The unreliability and uncertainty of the judicial process also has a negative impact on growth and investment. Nevertheless, repeated attempts at placing judicial reform on the political agenda and introducing external oversight have failed to overcome the defensive corporate culture of the judiciary and its strict interpretation of the principle of separation of powers. Confronted with more pressing reforms and concerns, President Fernando Henrique Cardoso has been unable to craft a sufficient coalition to support judicial reform. Consequently, "without more sustained pressure for judicial reform, the ability of the courts to resist reform efforts becomes much easier" (96).

In many ways, the case of Argentina illustrates the opposite dangers: the excessive politicization of justice, especially during the presidency of Carlos Menem (1989-1999). The failure of judicial reform in Argentina partly derives from the inadequacy of the gradualist approach adopted. According to Prillaman, "despite the claims of reform experts, narrowly targeted incrementalism in judicial reform does not produce gradual improvement; it produces a negative synergy that contributes to a failed reform and democratic decay" (112). Three main reasons have contributed to undermining judicial independence and undercuting the credibility of the courts. First, in the early 1990s, Menem was wary that an excessively zealous judiciary would challenge the legal bases of the executive decrees adopted to implement sweeping market reforms. Second, Menem's obsession with seeking reelection in 1995, which entailed amending the Constitution, also required a pliant judiciary. Finally, the concern that an independent judiciary capable of checking the executive branch could hold the administration accountable for its flagrant corrupt practices, especially in the context of privatizations, was a decisive factor. Hence, one of Menem's first targets was to neutralize the potential threat of an excessively independent judiciary. Menem used a number of tactics to mould a more docile judiciary, ultimately packing the Supreme Court in 1990. He thus kept the illusory façade of democracy while neutralizing the horizontal mechanisms of accountability that an independent judiciary would have provided. 


\section{Judicial Governance and Economic Reform}

Another puzzling paradox uncovered by Prillaman's insightful analysis resides in the intricate interplay between judicial reform and economic reform. While the swift and decisive decision-making needed to implement first-generation market reforms often requires a pliant judiciary, second-generation economic reforms aimed at anchoring the institutional foundations of the market economy require precisely the opposite. Market-oriented economic reforms are not sustainable without restoring and strengthening the credibility of the rule of law. As the reliability of the legal and judicial process increases, so does the credibility of the public policymaking process. More fundamentally, government by executive decree, while an asset in the initial phase of economic reform, progressively becomes a liability in the second phase of reform.

Indeed, a striking aspect of Argentina's judicial reforms has been their economic thrust. President Menem brought the courts under greater presidential sway at the outset of his decade-long tenure. In doing so, he secured his sweeping market reforms and privatization program by reducing the judicial "veto points" in economic policymaking. The experiment backfired, however, as the politicization of the judiciary progressively became a liability, as it increased legal uncertainty and judicial insecurity. It is thus not surprising that, in the midst of the economic collapse of the winter 2001-02, the Supreme Court became a prime target of protesters, leading to the initiation of an impeachment trial by the Argentine Congress in early 2002. The lack of judicial security has also undermined the credibility of the entire policymaking process. The controversies surrounding the "economic subversion" and bankruptcy laws in early 2002 have delayed an agreement with the International Monetary Fund (IMF) on a rescue package. More fundamentally, the deterioration of rule of law and the expeditious modes of governance to which Argentine politicians have become accustomed have dramatically eroded the quality of democratic governance and people's confidence in the political elite.

The obstacles to effective judicial reform are a central concern of Justice Delayed: Judicial Reform in Latin America, edited by Edmundo Jarquín and Fernando Carillo from the Inter-American Development Bank (IADB), which integrates the views of policymakers, legal experts and aid practitioners. Santos Pastor aptly captures the main dilemma of judicial reform, suggesting that "in general, judicial reform lacks a homogenous and active social base capable of providing leadership in the hope of obtaining benefits greater than its costs" (59). For Edgardo Buscaglia, "the main obstacles to effective judicial reform in Latin America are the vested interests within the justice apparatus itself" (26) and the institutional inertia they generate. These political economy factors explain why, despite repeated attempts, few advances have been observed in practice.

Furthermore, the legal reforms adopted to comply with the requirements of the market economy have tended to undermine judicial efficiency, clogging the courts with relentless inflation in legislation. As Colombian legal scholar Rudolf Hommes notes, "an excess of legislation has created a legal morass that complicates 
court proceedings and decisions, so that the entire judicial system becomes erratic. Lack of transparency is one reason for the uncertainty of legal systems, as rules proliferate and the resulting confusion gives rise to creative interpretations and unpredictable court decisions. Another cause of uncertainty is corruption" (48). The credibility of economic policy is particularly affected by these negative synergies, undermining the legal system underpinning state policies and government commitments. Were people to believe that the courts would hold governments to their legally binding commitments, they would be more willing to act in accordance to policy decisions. In such contexts, the justice system often becomes an instrument of politics.

\section{Why is Judicial Reform so Elusive?}

Judicial reform is confronted with a formidable paradox: why should politicians decide to limit their own power? In Elusive Reform: Democracy and the Rule of Law in Latin America, Mark Ungar tackles judicial reform in the broader context of the governance of the state, as the rule of law requires "a law-abiding state" (17). Contrasting the experiences of post-1983 Argentina and post-1958 Venezuela, he unveils another paradox of the political economy of rule-of-law reform. He argues that the very reasons motivating policymakers to enact reforms are the same conditions that inhibit effective judicial reform and obstruct meaningful change. The excessive executive dominance of the policy process and the internal disarray of the judicial system first motivate but then hinder effective judicial reform. "Once in place, reforms must confront the same conditions that gave rise to them: a repressive or unresponsive executive power, and an inefficient or inaccessible judiciary" (4). According to Ungar, executive power and judicial disarray explain why judicial reform is so elusive, as "those responsible for creating it are also responsible for enforcing it" (2). Reformers must confront both the political incentives shaping judicial performance and the bureaucracy responsible for administering justice.

Elusive Reform focuses on the rule of law, rather than merely on the judiciary. As such, it addresses broader political and institutional issues. It underscores that the challenges of state reform reside in strengthening the accountability and responsiveness of the state and promoting society's adherence to and confidence in the law. Indeed, the rule of law constitutes the principal mechanism for restraining the state. The effectiveness of the rule of law not only depends on the efficiency of the judiciary but also on a range of non-judicial state agencies, such as the police force and the prison system, especially in the improvement of criminal law and penal codes. Ungar makes the useful distinction between managerial reform and judicial institutionalization. While the first kind aims at enhancing the internal effectiveness of the administration of justice, the objective of the second type of reform is to improve external accountability of state agencies such as the police forces, the judiciary and the penitentiary system.

Furthermore, Elusive Reform makes an evaluation of the effectiveness of recent institutional innovations, such as ombudsman offices and judicial councils. In the 
case of Defensorias del pueblo, political meddling and obstruction often have frustrated initial expectations. While executive authorities, under internal and external pressure, have agreed to the establishment of such agencies of restraint and oversight, they have hampered their effective functioning by failing to enact swiftly the necessary legislation, allocate sufficient financial resources and appoint impartial ombudsmen. When a Defensoría eventually becomes operational, "its actual functioning is still shaped by executive politics and state bureaucracy" (39). When it tests the limits of its power, "the usual response is negligence, stalling or attack" (39).

Similarly, the establishment of autonomous judicial councils, once heralded as the miraculous cure to judicial inefficiency, has thus far produced mixed results. Modeled on the 1974 Italian and 1978 Spanish councils to enhance the political independence of the judiciary and improve its administrative management, their effectiveness has nevertheless been hampered by the same factors they were created to address, namely executive power and judicial disarray. In Venezuela, one of Latin America's first democracies to establish such a council in 1961, the council eventually succumbed to the attacks of all three branches of government and was dissolved in 1999. In an authoritative essay evaluating the performance of judicial councils throughout Latin America, Linn Hammergren (2002) aptly demonstrates that the creation of judicial councils per se is no magic bullet for effective judicial reform. There exists great variation in the roles, composition and nomination procedures, which oblige to distinguish different types of councils. She convincingly argues that "this purported remedy for a number of judicial ills is less automatic and more complicated than usually depicted" (Hammergren, 2002:1).

What is paradoxical with these institutional innovations is their underlying logic, as they intend to achieve their stated objectives by removing key dimensions of judicial administration from the purview of judiciary authorities. Defensorias are to check the executive branch by palliating the deficiencies of public prosecution. Similarly, judicial councils are to resolve the inadequacies of the pyramidal structure of judicial governance supervised by the Supreme Court. Indeed, many democracy promotion efforts have tended to establish new institutions to solve old governance problems, offering technical solutions to political problems and often transposing models imported from abroad. They have thus far failed to enhance the effectiveness of existing political institutions and alter the incentive structure shaping judicial governance. Such institutional innovations tend to circumvent the core problem of politicization. They illustrate the defining challenge of judicial reform in Latin America: making the judiciary actually work. As Linn Hammergren (2002:35) underscores a "common feature throughout the region is the failure to admit that the underlying problem is inadequate judicial institutionalization, not too little independence".

\section{The Brazilian Outlier}

The case of Brazil, which has largely been neglected in comparative analyses of judicial reform in Latin America, is an anomaly in the region. Brazil is largely 
"outlier" in terms of judicial governance: its judiciary needs reforming not so much because it lacks independence, but rather because it is excessively independent. However, the Brazilian model of judicial governance constitutes an example of things to come in the region, as judiciaries, for a variety of reasons, are acquiring greater independence. The challenge of judicial reform thus resides in strengthening the countervailing mechanisms of accountability and oversight in order to enhance the judiciary's social responsiveness and political responsibility. Judicial reform is nevertheless likely to gain greater prominence in the political agenda following the historic victory of Luiz Inacio Lula da Silva in the presidential elections of October 2002. His campaign commitments included in particular tackling systemic corruption and overhauling the judicial system.

Despite numerous attempts, judicial reform has eluded Brazil. In Reforma do judiciário editor Maria Tereza Sadek aptly assesses recent efforts at reforming the judiciary during the 1990 s, providing a rigorous and informed account of the political economy of judicial reform (or lack thereof). Successive reform proposals shared three concerns: "enhancing the administration of justice, broadening the access to justice, and democratizing judicial institutions" (177). However, since the restoration of democracy in 1985, the Brazilian judiciary has proved extremely skilled at resisting reform, anchoring its strategy in a strict interpretation of the principle of the separation of powers and the system of checks and balances enshrined in the Constitution. Reacting to the country's authoritarian past, the Constitution of 1988 consecrates the structural independence of the judiciary and the individual independence of judges. Nevertheless, constitutional provisions for judicial independence have created a fragmented and inefficacious system for administering justice.

As Reforma do judiciário underscores, working through the labyrinth of Brazilian politics has proven particularly damaging to the articulation of a comprehensive strategy for judicial reform. In June 2000, the Chamber of Deputies finally adopted a much-diluted proposal for a constitutional amendment, which had been introduced in 1992 by PT's Hélio Bicudo. The proposal that is currently being considered by the Federal Senate is the result of protracted political negotiations in the parliamentary commission on judicial reform established in 1995 and initially chaired by PFL's

Jairo Carneiro. The absence of a minimal consensus within the parliamentary commission itself prevented a vote on the proposal put forward in 1996. The commission ended its work in 1998, without being able to define the broad contours of a reform project. However, it was reactivated in 1998, as a response to allegations of mismanagement in the judiciary, which had had become a prime target of Antonio Carlos Magalhães's crusade against corruption. Furthermore, the slowness and unreliability of the judicial process were recognized as major impediments to economic development and market-oriented reform, imposing an added "Brazilian cost" for doing business. A discredited judiciary had progressively become insulated and unresponsive, a tendency that has significantly undermined its legitimacy and credibility. 
In early 1999, the commission's rapporteur, Aloysio Nunes Ferreira (from the governing PSDB), delineated the three main axes for judicial reform: the creation of an institution of external control, with administrative and disciplinary functions; the rationalization of the judicial decision-making; and the modernization of the administration of justice. His successor, Zulaiê Cobra Ribeiro, introduced even more stringent mechanisms of external oversight. The commission nevertheless diluted her project and when the Chamber of Deputies finally adopted the text in 2000, political parties had further altered it.

As Reforma do judiciário demonstrates, judicial reform in Brazil is marked by an intractable paradox. Despite its importance in the public debate over the last decade, it has proven extremely difficult to craft a sufficient consensus on the shape of the reforms required, devise a credible reform project, and create a coherent proreform coalition. The three most contentious aspects of judicial reform include: clarifying the mechanisms for judicial review and rationalizing the system of control of constitutionality; strengthening the mechanisms of accountability and external control by creating a judicial council; and improving access to and administration of justice. As Sadek and Rogério Bastos Arantes underscore in the introductory chapter, judicial reform in Brazil has two principal dimensions. The first dimension concerns the internal structure and administrative efficiency of the judiciary and is part of the broader process of the modernization of the state. The second dimension concerns the role of the judiciary in the democratic system of institutional checks and balances and the respective powers of the three branches of government, especially considering the fact the judiciary is the only non-elected democratic institution. While administrative reform has received broad support, encroachment to the constitutional principles of the independence of the judiciary and the separation of powers has been fiercely resisted by the judicial hierarchy, with the side-effect of derailing promising administrative and organizational reforms. As a result, beyond technical improvements, a comprehensive reform of the Brazilian judicial system remains elusive.

A flagrant example of the perverse nature of Brazilian justice system and the dangers of excessive independence is found in the system of the review of the constitutionality of laws provided for by the 1988 Constitution. As Arantes convincingly argues in his contribution, judicial review has often been used, abused and misused for political purposes, as a result of the "judicialization of politics" (Vianna et al., 1999) and judicial activism. The Constitution has established a hybrid system of judicial review whereby almost every court can decide on constitutional issues. Consequently, a major thrust of reform proposals has been to rationalize judicial review by concentrating it on the Supreme Federal Tribunal (STF) and making its decisions binding on lower-level courts.

The decentralized nature of the Brazilian judicial system is reflected in the fact that lower-court judges are not necessarily bound by the decisions of the STF in constitutional matters, creating a "balkanized" legal system where each court acts as an insulated entity. While acting as a constitutional court, the STF neither possesses the corresponding powers of enforcement, nor the exclusive authority over 
the declaration of (in)-constitutionality of laws (Arantes 1997). Furthermore, the level of detail of constitutional provisions is such that almost any dispute can become constitutional. As a result, the STF was soon overloaded with judicial recourses on constitutional grounds. The challenge thus resides in establishing a sharper hierarchy of laws, converting the STF into a genuine constitutional court.

However, the proposal for rationalizing and concentrating judicial decisionmaking has been strongly resisted by lower-court judges who have jealously defended their independence. Political parties have also fiercely resisted concentration because, as Arantes aptly demonstrates, the judicial system is a particularly effective tool for doing politics by other means. The opposition considers the hybrid nature of the judicial system as a political instrument that enables it to contest, delay and dilute government policies, especially in the economic realm. The "politicization of justice" tends to transform 'judicial institutions into a locus for obstruction of the political majority by the political minority' (38) by means of judicial recourses.

More fundamentally, the debate over constitutional judicial review reflects the tensions between parliamentary prerogatives and judicial independence. For Arantes, the fundamental debate concerns the "very nature of superior tribunals of justice and their legitimacy to have the last word on specific types of cases" (43). The central issue is thus linked to the internal architecture of the judicial system and the hierarchy of judicial authorities. Regrettably, the judicial reform agenda resembles, using Arantes' metaphor, a "chaotic building site" that lacks an overall architectural plan. Successive ad hoc reform efforts "do not reflect a harmonious and coherent project and end up creating new sources of instability in the judicial apparatus" (89).

A second important dimension of the required judicial reforms concerns the need to strengthen the mechanisms of accountability and oversight, in particular of external control. The creation of an institution of external control responds to the pressing demands for increasing the transparency in and accountability of the judiciary, in the broader process of institutional modernization and political democratization. Proposals for establishing a judicial council emerged and gained momentum in the early 1990s, as most Latin American countries adopted this institutional devise to enhance the independence of their judiciaries. However, the creation of a judicial council has been extremely controversial. Sadek compares and contrasts the successive proposals and shows that the controversies centered on both its opportunity as well as its mandate, competencies and composition. In principle, the rationale for creating a judicial council resides in its ability to rationalize the administration of justice and anchor the independence of the judiciary. In Brazil, however, the motivations for establishing such a judicial council are different. The prime objective is to strengthen accountability, oversight and control by modernizing the internal functioning of the judiciary, rationalizing the use of human and financial resources, and preventing nepotism, corruption, mismanagement and waste.

Since the constitutional convention that drafted the 1988 Constitution, most proposals for judicial reform have included considerations over the external control 
and oversight of the judiciary. However, the debate has progressively shifted in the course of the 1990s. In the early 1990s the creation of a judicial council was fiercely resisted on the grounds that it encroached on the independence of the judiciary and the constitutional principle of the separation of powers. By the end of the decade, it was considered compatible with and even indispensable to the consolidation of democracy, as it would enhance the responsiveness of the judiciary to social demands. A consensus progressively emerged concerning the mandate and attributions of a judicial council, grounded in the need to dramatically improve the internal administration of judicial resources. However, the composition of the judicial council proved to be a more contentious issue, in particular as it concerns the inclusion of representatives of non-judicial professions. The final version of the project approved by the Chamber of Deputies included a significant number of external members from civil society.

Sadek shows that those actors more actively resisting reform are to be found in the legal profession itself and the judicial hierarchy in particular. However, the judicial profession is not a homogeneous entity and its position has changed over time. While in the early 1990s most magistrates opposed the creation of a judicial council, by 2000 most of them supported it, although they favor an institution composed primarily of judges and jurists. Moreover, while senior and superior judges tend to resist reform, lower-level judges favor it. Proponents of judicial reform also include a majority of public prosecutors, the government and the ruling coalition, as well as lawyers, civil society organizations and trade unions. The private sector has also expressed increasing concern, if not frustration, with the lack of reliability of the judicial system and credibility of judicial decisions, especially in the field of commercial law and litigation. Most parliamentarians favor the creation of a judicial council, especially senators. Amongst political parties, the PT is the most active proponent of judicial reform and the establishment of mechanisms for social control and political accountability.

So, why has judicial reform proved so elusive in Brazil? At the root of the intractable dilemma of judicial reform in Brazil are the age-old dynamics of political economy (Geddes, 1994): support for judicial reform is diffused and gains from it are long-term while resistance to judicial reform is concentrated, as are short-term potential losses.

\section{THE INTERNATIONAL PROMOTION OF JUDICIAL REFORM}

In the course of the 1990s, international financial institutions such as the World Bank and the IADB as well as government agencies such as the United States Agency for International Development (USAID), have funded an increasing variety of judicial reform projects (Ciurlizza, 2000). However, the effectiveness of such initiatives is yet to be evaluated.

The experience of Venezuela is particularly instructive regarding the influence of external involvement in judicial reform. It was the scene of one of the first and 
largest externally funded judicial reform project in Latin America. It was also one of the first to be cancelled due to political meddling in judicial governance (World Bank 2002c). Approved in 1992, it amounted to US\$24.5 million and was originally to be implemented over five years (1992-1997). Similarly, political interference in judicial governance and unrelenting attacks on judicial independence by the administration of President Alberto Fujimori led to the suspension and cancellation of a US\$22.5 million loan to reform the Peruvian judicial system in 1998.

\section{Evolving Targets and Shifting Agendas}

In the Rule of Law in Latin America: The International Promotion of Judicial Reform, a group of practitioners reveals its assumptions and describes the strategies they deploy to overhaul judicial systems. Although the volume relies on contributions by individuals managing rule-of-law programs in donor agencies and thus tends to lack critical distance and objectivity, it attempts to evaluate the varying approaches to the international promotion of the rule of law: What is their underlying logic and rationale? How successful have they been? While the volume remains largely silent on the latter question, it sheds new light on the former.

A paradoxical finding of the study is that, despite addressing such a politically sensitive issue as judicial reform, bilateral and multilateral donors resist entering the political arena. According to Domingo and Sieder, "there are two areas of reform which would directly address the problem of 'horizontal accountability' and enhance the principle of separation of powers: the independence of the courts; and the extent of judicial review powers vis-à-vis the other branches of the state. As these are overly political questions, international donor organizations have generally been shy of pursuing reform initiatives that engage in these two questions" (154). This tendency is evident in the World Bank's approach to judicial reform in Argentina (World Bank, 2001).

Another question concerns the evolving agenda of rule-of-law promotion. As Thomas Carothers aptly remarks, while the rule of law as a goal of national policy or international co-operation has gained undisputed eminence in the current discourse on democracy promotion, "the term means different things to different people. [It] is such a broad concept as to be capable of covering many different activities" (4). In the course of the 1990s, the judicial reform agenda came to encompass an increasing number of concerns and pursue multiple goals. Carothers identifies four main clusters of rule-of-law work, which originate from distinct traditions of development assistance - democracy promotion, economic reform, human rights and social justice, and police reform and law enforcement. He argues that the four different clusters are not always "fully compatible and points of tension arise in practice" (12). This explains why the objectives pursued by donor agencies may, at times, diverge, if not conflict. In particular, while the economic approach to judicial reform emphasizes efficiency in commercial law, the political one tends to target judicial independence and criminal law.

Similarly, assessing the evolving targets and shifting agendas of judicial reform, 
Luis Salas points to another feature of rule-of-law work which inhibits its political thrust. As the legal profession dominates it, the international promotion of judicial reform approaches justice reform as a technical endeavor aimed at bettering the laws, enhancing their administration and improving their enforcement. As a result, it often overlooks the wider political economy context. However, the new rule-oflaw reform movement of the 1990s has considerably enlarged the horizons of legal and judicial reform in the context of the "democratic neo-liberal market model" (22). Concerns have broadened from the exclusive focus on the impartial application of laws to include greater attention to their democratic credentials. The ruleof-law agenda is still evolving within donor institutions and tremendous progress has been achieved in recent years. Furthermore, it would be a mistake to consider these actors as unitary actors: they, too, are the locus of reform and power struggles where diverging interests compete for prominence.

\section{The Role of Multilateral Development Banks}

Multilateral development banks (MDBs) have become intensively involved in rule-of-law reform in developing countries and transitional economies. Since it entered the field of judicial reform in 1991, the World Bank has financed 480 projects in 84 countries that deal with, or include components of legal and judicial reform, totaling \$380 million. Between 1991 and 2001, the Bank approved 35 projects exclusively devoted to judicial reform. It has also established targeted lending instruments and upgraded its own capacities to assess judicial performance and promote judicial reform by undertaking Judicial Sector Assessments since 1994 (in Ecuador) and, since 1999, more comprehensive Institutional and Governance Reviews. The largest judicial reform projects were undertaken in Venezuela (\$60 million) and Russia (\$58 million). Furthermore, the Bank’s Legal Vice Presidency has provided legal advice to over 87 countries in over 45 specialized areas since 1986 and training in legal and judicial reform has also become a core activity of the World Bank Institute (World Bank, 2002a).

Initially, projects tended to focus almost exclusively on technical issues such as improving infrastructure and building technical capacity. However, MDBs realize that the effectiveness of their projects critically hinges upon the political context. Consequently, they are increasingly engaging in comprehensive institutional reform addressing the incentive structure affecting judicial performance. A main lesson learned of a decade of rule-of-law promotion is that the government's political will is a sine qua non condition for meaningful and lasting reform, but donors often misread or overlook it. For example, the 1992 auto-coup by Alberto Fujimori in Peru was followed by several efforts at judicial reform supported by the World Bank, the IADB and bilateral donor agencies. The strategy sought to overcome the politicization of the judiciary by creating a judicial council. However, the government and Congress emptied the council of its prerogatives and transferred them to the politically lenient Supreme Court and the Public Ministry. All members of the 
Judicial Council resigned in protest and, ultimately, the World Bank had to cancel its project.

The World Bank subsequently recognized having misread and misjudged President Fujimori's authoritarian tendencies, as by 1997 "there were clear indications that the government was not committed to public sector reform" (World Bank, 2002b:18). ${ }^{1}$

In Rule of Law in Latin America, Maria Diakolias from the World Bank underlines that creating broader constituencies for reform, especially within civil society, is critical to circumventing the lack of commitment of politicians and overcoming the resistance of the judicial hierarchy. This realization reflects the obvious fact that judicial reform is essentially a domestic process. As for foreign aid in general, the external promotion of the rule of law has clear limitations. Diakolias concedes that the Bank remains inhibited by the restrictive economic mandate and its technocratic ethos. While it has significantly increased its capacities for assessing judicial performance, it remains ill equipped to craft and steer complex and politically-charged processes of rule-of-law reform.

The Bank's approach is now enshrined in the governance strategy of November 2000, which was made further explicit in April 2002 (World Bank, 2002b, 2000). ${ }^{2}$ Building on the World Development Report of 1997 on the changing role of the state, Reforming Public Institutions and Strengthening Governance openly confronts the dilemmas of the Bank in addressing the politics of judicial reform. For the Bank, the rule of law is a system based on three pillars: rules, processes and institutions. "The first pillar consist of objective rules that not only are known in advance but are actually enforced and are subject to modification or termination pursuant only to previously known practices. The second pillar consists of the processes that ensure that the rules are not arbitrary, in other words that they are adopted in response to genuine needs of the people and applied and enforced to serve these needs. [...] The third pillar consists of well-functioning institutions that operate in a transparent way and are accountable to citizens, institutions that adhere to and apply regulations without arbitrariness" (Shihata, 1995:13). The Bank focuses exclusively on those aspects of the judicial system that affect economic performance, in particular competition and commercial law, taxation, rules of foreign investment. Improving access to justice is nevertheless becoming an area of increasing concern for the Bank in its renewed focus on poverty reduction.

On the positive side, the new strategy broadens the initial approach to governance reform and the rule of law articulated in the early 1990s by emphasizing the

\footnotetext{
${ }^{1}$ The Bank's Peru Country Assistance Evaluation of 2002 further argues that "the Bank inappropriately redirected resources from investment to fast-disbursing adjustment loans, especially given the reversals on macroeconomic and structural adjustment fronts and allegations of corruption" (World Bank, 2002b:18).

${ }^{2}$ In recent years, the MDBs have revisited their governance assistance strategies, starting with the World Bank in 2000, the African and the Asian Development Banks in 2001, and the Inter-American Development Bank in 2002, thus marking the emergence of a second generation of governance strategies.
} 
need to empower citizens and foster accountability. The Bank now grounds its work on more comprehensive analytical assessments and a broader array of lending and non-lending instruments. Echoing the 1997 World Development Report, it recognizes the critical role of political incentives in shaping judicial performance. Yet, in line with its economic rationale, it sets explicit limits on its involvement in legal and judicial reform, stating that areas of intervention should exclusively target commercial, contract and corporate law as well as property rights. The strategy does not envision the Bank becoming involved either in criminal justice systems and penal code reform, or in police and prison reform. As such, the Bank's action plan tends to endorse the very "enclavist approach" it criticizes. It has now been amply demonstrated, including by Prillaman and Ungar, that insular judicial reforms implemented in a piecemeal fashion are bound to fail if they do not address the broader institutional context of judicial governance. As Domingo and Sieder underscore, "under the label of neutral technical expertise, international donors' policy proposals can fail to take into consideration not only specific national political and social conditions, but also the complexity of power relations at the level of policymakers and within the particular agency which is targeted for reform" (146).

The MDBs tend to adopt an instrumental approach to the rule of law reform, evaluating judicial performance in efficiency terms. This intellectual approach is reflected in the World Bank's World Development Report of 2002: Building Institutions for the Market. The rule of law is mainly conceived as a means for sustaining market reforms, not an end it itself in terms of democracy and social justice. While there exist sound arguments to justify this instrumentalist approach, it is nevertheless too restrictive and largely inadequate. It is also strategically counterproductive, as it overlooks the political nature of judicial reform and the political economy of coalition building. Sustaining judicial reform and enhancing the performance of the courts not only requires neutralizing opposition, but more fundamentally building coalitions of support that will oversee the reform process and enforce accountability.

As Lawrence Tshuma (1999) convincingly argues in a recent essay, a "problematic issue with the new institutional economic explanation of law and the Bank's legal framework is their use of the efficiency criterion to evaluate law" (92), at the expense of broader concerns such as ethical considerations and democratic principles. Tshuma underscores the fact that the "Bank's attempt to strip law of ethical and normative aspects is flawed both in principle and in practice" (94). Indeed, as Salas suggests, the legal profession, which dominates the rule-of-law promotion, has often failed to adequately consider political factors in the design and implementation of judicial reform projects. By proposing technical solutions to political problems and succumbing to the illusory charms of technical expertise, they have become vulnerable to the temptation of "institutional modeling" (Carothers, 1999), replicating their own standard models of judicial organization and functioning in the context of the many realities of Latin American countries.

Judicial reform must be inserted into the broader context of the redefinition of the state. The paradox is that, while rule-of-law promotion appears dominated by the neo-liberal paradigm that advocates a drastic reduction in the prerogatives 
of the state, strengthening the rule of law requires a stronger state capable of enforcing law and exercising effective legal control over its territory. A capable state is required to guarantee public security and the rule of law, necessary conditions for both economic development and democratization. Markets require a legal and regulatory framework that only governments can provide. Secure property rights, appropriate legal and financial institutions, adequate contract enforcement, sound financial and banking regulations, effective oversight bodies and effective regulatory agencies are all aspects of good governance.

The IADB's approach to judicial reform has broader political goals enshrined in the expansion of its mandate in 1994, which now includes the consolidation of democracy as one of its objectives. In her contribution to Rule of Law in Latin America, Christina Biebessheimer from the IADB provides a useful overview of IADB judicial reform projects. The IADB's policy on the modernization of the state was first articulated in 1996 and is currently being revised. Between 1993 and 2001, the IADB approved 18 loans and 65 technical co-operation operations to reform judicial systems and modernize the administration of justice in 21 of its 26 member countries, amounting to $\$ 461$ million in investment over the past eight years (Biebessheimer and Payne, 2001). While the IADB's approach to institutional strengthening is similar to that of the World Bank, the substantive focus of its judicial reform initiatives diverges substantially. In particular, civil and criminal law is considered within the purview of its expanded mandate. Furthermore, the IADB engages more actively in building political support and consensus for judicial reform. As a regional MDB, it tends to enjoy closer ties with national policymakers (sometimes too close).

The comparison between the World Bank and the IADB is particularly useful, as it reveals a fundamental divergence in approach. While IADB judicial reform projects are designed in response to a demand from its member states, the Bank's projects tend to accompany larger structural adjustment loans, often packed as a condition attached to them. Indeed, this difference partly explains the fact that the IADB has a higher proportion of loans to technical assistance.

\section{The Contribution of Donor Governments}

Donor governments and their aid agencies have been at the forefront of the international promotion of judicial reform, pushing this agenda within the multilateral institutions of which they are members. USAID is one of the main providers of rule of law assistance, especially in Latin America, and one of the first to have entered this area. In Latin America alone, USAID spends 13 percent of its regional budget to promote democracy, half of which is targeted to strengthen the judiciary. Rule-of-law programs represent approximately $\$ 50$ million a year (figure for 1999).

In recent years, USAID has sought to enhance its professionalism in promoting the rule of law abroad. The contribution by Margaret Sarles from USAID to Domingo and Sieder's Rule of Law in Latin America reflects the learning curve within USAID. However, like most bilateral donors, USAID is reluctant to frontally engage 
in the political arena, as it tends to target specific areas of judicial reform without confronting the core problems of political incentives shaping judicial performance. As a result, the template of interventions and the menu of options lack an overall strategic thrust in terms of sequencing and prioritization. As Sarles underscores, "the lesson here is that a successful strategy of justice reform needs to consider the entire panoply of relevant institutions" (53). Yet, bilateral donors, which must respond to the demands of their own varied constituencies, resist narrowing down their focus in any specific country within a broader framework of donor co-ordination. This tendency inevitably leads to duplication of effort and a multiplication of stand-alone initiatives, often in open competition with one another.

Salas recognizes that "co-operation among donors has been the exception, not the rule" (38). Indeed, legal technical assistance is provided from a variety of sources, each with its specific set of objectives, conceptual assumptions, reform targets and implementation strategies. The lack of inter-agency coordination (which often adds to the lack of coordination within recipient governments) is particularly damaging considering the diverging and, at times, conflicting approaches to legal and judicial reform. For example, in the past few years, 26 programs in 15 reform areas are being pursued to reform the Nicaraguan justice system, without much success. Lack of coordination is not limited to international cooperation but does also occur within the same donor government and the vast myriad of state institutions, quasi-public organizations and non-governmental organizations providing assistance to judicial reform. More fundamentally, as Rule of Law in Latin America underscores, while this irresistible penchant for solitude is due to a wide variety of factors characteristic of development co-operation, it is ultimately rooted in the weak theoretical framework underlying the foreign funding of legal and judicial reform.

However, and unlike many other aid agencies, USAID has made sustained efforts to enhance its skills and capacity to assess judicial performance and design effective rule-of-law programs. In the late 1990s, it has funded an array of research to sharpen its approaches to democracy promotion, which is one of the three core objectives or "pillars" of the agency following the reform of the agency in 2001. It has produced a series of handbooks to guide project managers in the design of assistance programs. In November 2000, it completed a voluminous 214-page Guidance for Promoting Judicial Independence and Impartiality. The Guidance harvests the lessons learned during the last decade and contains elements of a strategy in terms of targeting and sequencing. It follows other technical instruments such as a framework for conducting democracy and governance assessments (November 1998) and a handbook of democracy and governance indicators (August 1998).

The Guidance goes beyond what one would normally expect from a technical document from an aid agency. It addresses a wide range of critical issues in judicial reform, including a comparative assessment of institutional arrangements shaping judicial governance and key themes, illustrated by regional and country case studies. In particular, it reflects a shift of emphasis from an exclusive focus on strengthening the independence and efficiency of the judiciary to the balancing concern of enhancing impartiality, transparency and accountability. In her insightful contribu- 
tion, Linn Hammergren underlines the diverging conceptualization of such broad concepts as judicial independence and accountability, as well as the tensions that arise between them. Exploring the conceptual foundations of these concepts, she shows the "shifting balance in reform goals" (147) over the last decade.

\section{TENTATIVE CONCLUSIONS: TOWARDS FEASIBLE REFORMS}

These recent developments reflect a pressing concern within aid agencies to assess judicial performance and evaluate the impact of their assistance programs. There is heightened recognition that, after a decade of rule-of-law promotion, time has come to evaluate its impact more systematically. The books reviewed herein participate in this effort towards a greater systemization of rule-of-law work, after what has largely been a decade of improvisation. In this regard, several issues merit particular attention.

First, and although progress has been made in recent years, rule-of-law promotion remains irresistibly tempted by the mirage of "institutional modeling" captured by Thomas Carothers (1999). It continues, consciously or unconsciously, to replicate and transpose the legal and judicial systems of developed countries in developing countries and transitional economies. Much like the Kemmerer missions of the 1930s, there is a tendency in the rule-of-law promotion community to rely on standard models and to assess the performance of a developing country's judicial system against these exogenous standards. ${ }^{3}$ It is often assumed that institutional transposition will be accepted and assimilated by the recipient organism and will enhance judicial performance. The rational model underpinning neo-modernization theory tends to assume that technical sophistication will automatically receive political acceptance. However, as the case of judicial councils has shown, this assumption no longer holds.

Second, the various books reviewed reflect a gradual learning curve and the increasing recognition of the complexity of comprehensive legal and judicial reform, including the potential tensions and even contradictions among the various areas of rule-of-law reform. They also question the anchored belief that formalist rule of law, which stresses institutionalized legal mechanisms and absolute autonomy from politics, is sufficient to promote economic development and consolidate democracy. It was naively assumed that the adoption of new laws and the creation of new judicial institutions would suffice to anchor the rule of law. Unfortunately, the reality is far more intricate. Many well-designed laws are simply not enforced. Until recently, more attention has been paid to enacting new laws and regulations than ensuring compliance. However, as Stephen Holmes (1999) shows, law enforcement

\footnotetext{
${ }^{3}$ In the late 1920 s and early 1930 s, the Kemmerer missions, sponsored by the US government, revamped Latin America's banking systems and legal frameworks to better accommodate the requirements of US foreign investment (Drake, 1989).
} 
requires confronting the incentive structure of judicial functioning. Law reform is a political process and needs to be approached in the broader context of governance reform.

Third, one ought to reconsider the value of the "second best" option of feasible legal and judicial reforms. Current judicial reform efforts greatly undervalue it, as they aim to construct technically "perfect" legal systems. However, the best can be the enemy of the better. No system is ever 'perfect', as they are all in constant mutation. In a recent article, Florencio Lopez-de-Silanes (2002) accurately notes that in the case of corporate and bankruptcy law "the divide between developed and developing economies is more pronounced at the level of enforcement than in the laws themselves" (92).

He further argues that "the best reform strategy is not to create the ideal set of rules and then consider how to enforce them, but rather to enact rules that can be enforced within the existing enforcement structure" (113). As a result, as Hewko (2002) convincingly argues, "the emphasis of legislative reform should be on the details (not the general concepts) and on determining specific (very often mundane) changes that need to occur for existing legislation to function within the cultural, political, and economic realities of the host countries" (5). Indeed, "entrenched bureaucracies and sclerotic institutions are not commando units and assimilate change at less than lightening speed" (18-19).

Four, adequately reforming judiciaries is only part of the challenge. It is also the easiest. Strengthening the rule of law is a significantly more daunting task. It is an integral part of a broader process of behavioral change. The concept of the rule of law encompasses critical dimensions of social capital, community ethics and political behavior, which in turn affect trust in lawmaking and enforcement. Carothers (1999) makes the useful distinction between strengthening the administration of justice and promoting the rule of law. Indeed, there are three broad levels of rule of law reform. The first one focuses on the reform of the laws themselves through legislative reform. The second one addresses the architecture of the judiciary and the institutions of judicial governance. The third level concerns the society's trust in and adherence to the law.

Consequently, rule-of-law reform strategies can be grouped in three main categories: normative, institutional, and comprehensive. Normative legal reform entails principally changing substantive laws and regulations, while institutional reforms address judicial processes and procedures, such as legal public defense and alternative dispute resolution. Comprehensive rule-of-law reform approaches the judiciary as a core institution of democratic governance. It thus aims not only at enhancing the separation of powers and anchoring the independence of the judiciary within the state, but more fundamentally at altering the incentive structure of the political systems and the behavioral patterns of politicians and citizens alike. As Domingo and Sieder underline, "from a state perspective, the rule of law is about a territorially bounded institutional network of rules and regulations that are generally binding upon state and society. Rule of law reforms [...] reflect a necessary re-evaluation of the role of the state in terms of its relationship to society" (151). 
Ultimately, the two central goals of the rule of law are to ensure the effective protection of rights and liberties and enforce accountability in government.

\section{REFERENCES}

AGÜERO, Felipe, and STARK, Jeffrey eds. (1998) Fault Lines of Democracy in Post-Transition Latin America. Miami: North-South Centre Press, University of Miami.

ALESINA, Alberto, ÖZLER, Sule, ROUBINI, Nouriel and SWAGEL, Phillipp (1996) "Political Instability and Economic Growth", Journal of Economic Growth, vol. 1, n 2: 189-211.

ARANTES, Rogério Bastos (1997) Judiciário e Política no Brasil. São Paulo: Sumaré.

BIEBESSHEIMER, Christina and PAYNE, Mark (2001) IADB Experience in Justice Reform: Lessons Leaned and Elements for Policy Formulation. Washington DC: IADB Technical Paper. BUSCAGLIA, Edgardo (2002) “Comments”, Economía, vol. 2, n 2: 137-141.

CAROTHERS, Thomas (1999) Aiding Democracy Abroad: The Learning Curve. Washington DC: Carnegie Endowment.

CAROTHERS, Thomas (1998) “The Rule of Law Revival”, Foreign Affairs, vol. 77, n 2:95-106.

CIURLIZZA, Javier (2000) "Judicial Reform and International Legal Assistance in Latin America", Democratization, vol. 7, $\mathrm{n}^{\circ}$ 2: 211-230.

DIAKOLIAS, Maria (1995) "A Strategy for Judicial Reform: The Experience in Latin America", Virginia Journal of International Law, vol. 36, $\mathrm{n}^{\circ}$ 1: 167-231.

DOMINGO, Pilar (1999) "Judicial Independence and Judicial Reform in Latin America" in Andrea Schedler et al. eds. The Self-Restraining State: 151-175.

DODSON, Michael (2002) “Assessing Judicial Reform in Latin America”, Latin America Research Review, vol. 37, n²: 200-220.

DRAKE, Paul (1989) The Money Doctors in the Andes: The Kemmerer Missions, 1923-3. Durham: Duke University Press.

GEDDES, Barbara (1994) Politician's Dilemma. Berkeley: University of California Press.

HAMMERGREN, Linn (2002) Do Judicial Councils Further Judicial Reform? Lessons from Latin America. Washington DC: Carnegie Endowment Working Paper 28.

HELLMAN, Joel, JONES, Geraint and KAUFMANN, Daniel (2000) Seize the State, Seize the Day: State Capture, Corruption and Influence in Transition. Washington DC: World Bank Policy Research Working Paper 2444.

HOLMES, Stephen (1999) "Can Foreign Aid Promote the Rule of Law?”, East European Constitutional Review, vol. 8, $\mathrm{n}^{\circ}$ 4: 68-74.

HEWKO, John (2002) Foreign Direct Investment: Does the Rule of Law Matter? Washington DC: Carnegie Endowment Working Paper 26.

LINDER, Anja and SANTISO, Carlos (2002) The Predictive Powers of Country Risk Ratings. Washington DC: SAIS Working Paper 02/02.

LÓPEZ-DE-SILANES, Florencio (2002) “The Politics of Legal Reform”, Economía, vol. 2, n 2: 91 136.

MENDEZ, Juan, O’DONNELL, Guillermo and PINHEIRO, Paulo Sergio de eds. (1999) The (Un) Rule of Law and the Underprivileged in Latin America. Notre Dame: University of Notre Dame Press.

MESSICK, Richard (1999) 'Judicial Reform and Economic Development: A Survey of the Issues', The World Bank Research Observer, vol.14, no.1: 117-136.

O’DONNELL, Guillermo (1998) “Horizontal Accountability in New Democracies”, Journal of Democracy vol. 9, n 3: 112-126.

SANTISO, Carlos (2001a) "Democratic Governance and Second Generation Economic Reforms in Latin America”, Instituciones y Desarrollo, nº 8-9: 120-142. 
SANTISO, Carlos (2001b) "Democratic Consolidation and Economic Policy-making: The Paradox of Second Generation Reforms in Argentina during the 1990s", Contribuciones 4/2001:109-136.

SCHEDLER, Andreas, DIAMOND, Larry and PLATTNER, Marc eds. (1999) The Self-Restraining Stare:

Power and Accountability in New Democracies. Boulder: Lynne Rienner.

SHIHATA, Ibrahim (1995) "Legal Framework for Development: The World Bank's Role in Legal and Judicial Reform”, in World Bank, Judicial Reform in Latin America and the Caribbean: 13-16.

TSHUMA, Lawrence (1999) “The Political Economy of the World Bank's Legal Framework for Economic Development”, Social and Legal Studies, vol. 8, n 2: 76-96.

VIANNA, Luis Werneck, et al. (1999) A judicialização da política e das relações sociais no Brasil. Rio de Janeiro: Revan.

WEDER, Beatrice (1995) “Legal Systems and Economic Performance: The Empirical Evidence”, World Bank, Judicial Reform in Latin America and the Caribbean: 21-26.

World Bank (2002a) Country Assistance Strategy for Peru. Washington DC: World Bank.

World Bank (2002b) Reforming Public Institutions and Strengthening Governance: A World Bank Strategy — Implementation Update. Washington DC: World Bank.

World Bank (2002c) Initiatives in Legal and Judicial Reform. Washington DC: World Bank.

World Bank (2001) Argentina: Legal and Judicial Sector Assessment. Washington DC: World Bank.

World Bank (2000) Reforming Public Institutions and Strengthening Governance: A World Bank Strategy. Washington DC: World Bank.

World Bank (1995) Judicial Reform in Latin America and the Caribbean: Proceedings of a World Bank Conference. Washington DC: World Bank Technical Paper 280. 